\title{
Chapter 6 \\ OSCE and Civil Society in the Western Balkans: The Road to Reconciliation
}

\author{
Raffaele Mastrorocco
}

\subsection{Introduction}

In this article, I will elaborate on the efforts of the Organization for Security and Co-operation in Europe (OSCE) in pursuing reconciliation in the Western Balkans together with regional civil society. I claim that the process of reconciliation in the Western Balkans has produced so far mixed results, despite the strong involvement of international organisations in the region. In fact, after more than twenty years since the Yugoslav wars, the region has achieved limited progress in inter-ethnic rapprochement. Nevertheless, the OSCE is actively participating in the process concerning the promotion of dialogue and tolerance among the regional conflicting parties and stands out among the other international agents in pursuing the task, thanks to its inclusive concept of security. Furthermore, over the years, a flourishing civil society sector emerged as an outcome of the support provided by the international community, which recognises the fundamental role that civil society actors, being NGOs, women, youth or religious leaders, play in the process of democratisation and peace-building in post-conflict societies. In this context, the OSCE stands out as a firm supporter of civil society organisations present in the area as showed by the organisation's engagement with NGOs such as the Belgrade Center for Human Rights in Serbia or Vaša Prava in Bosnia and Herzegovina and by its efforts in allowing regional cooperation between different civil society agents as depicted by the initiatives 'Fostering NGO Human Rights Network in the Western Balkans Region' and 'Follow Us', among others. In this sense, the research contributes to making sense of the transformations and developments that the OSCE is undergoing by providing an overview of the organisation's activities and progresses in the Western Balkans.

\footnotetext{
R. Mastrorocco $(\varangle)$

Interdisciplinary Research and Studies on Eastern Europe (MIREES), University of Bologna, Bologna, Italy

e-mail: raffaele.mastrorocco@studio.unibo.it
} 
Western Balkans refers to six countries in South-Eastern Europe, namely Bosnia and Herzegovina $(\mathrm{BiH})$, Serbia, Montenegro, Kosovo, North Macedonia and Albania. The region is afflicted by the consequences of the Yugoslav wars of the 1990s and, although Albania was not directly involved in the turmoil, caused severe interethnic tensions and divisions that have threatened on multiple occasions the security of the region and of its citizens. Consequently, the international community took the lead in bringing about a resolution to the conflicts and then in fostering a process of reconciliation. Among the regional actors, the stabilisation of the area was perceived as something externally imposed and mainly linked to integration into the European Union. Despite the fact that the EU has assumed a greater role in the region as a stabilising factor, the actions of the involved countries are mainly aimed at accomplishing normalisation of relations in order to achieve EU integration, rather than showing true willingness to establish regional cooperation (Emini and Marku 2019). For this reason, the involvement of other international organisations such as the OSCE has led to more genuine outcomes in providing regional security, though with less resonance. Among the countries in the OSCE area, the Western Balkans witnessed a strong involvement of the OSCE since its first mission was launched in Macedonia in 1992. At the time of writing, the organisation still puts much attention into the region to ensure security, as shown by the large budgetary deployment for its missions in the Balkan countries, with the OSCE Mission in Kosovo being the first recipient among all the field operations with a total budget provided of around EUR 17 million and the OSCE Mission in Bosnia and Herzegovina receiving around EUR 11 million (OSCE 2019). The peculiarity of the participation of the organisation in the Western Balkans stands in its approach to security issues that encompass all the dimensions of security, thus having a more comprehensive approach to reconciliation, which in turn requires the inclusion of all strata of society. Against this background, taking into consideration the contribution of the OSCE to supporting local civil society in the process of reconciliation is essential in order to outline the developments and transformations that this particular OSCE region has experienced.

The structure of the article is twofold. First, it provides the reader with a brief account of what reconciliation means and how it was pursued in the Western Balkans, also focusing on transitional justice, and it depicts the potential of involving civil society and international organisations in the process as well as its shortcomings. Then, I will move forward by presenting the activities of the OSCE in the region intended to pursue reconciliation, initiatives undertaken by it in boosting inter-ethnic rapprochement, and how the organisation is supporting civil society for these purposes. I will conclude that the OSCE, despite its weak financial capabilities, is a key agent in the region in fostering positive transformative changes also due to its strong support for local civil society. 


\subsection{Reconciliation in the Western Balkans and the Interplay Between Civil Society and International Organisations}

The concept of reconciliation has been increasingly used in relation to the involvement of the international community in the Western Balkans in the aftermath of the turmoil that affected the region in the 1990s. However, the very beginning of the appearance in the academic literature of the term 'reconciliation' linked to the peacebuilding initiatives in the Western Balkans, the academic community has not agreed on a common definition. Bloomfield (2003) proposes a definition of reconciliation as the process of dealing with past conflicts in an effort to develop a degree of cooperation, based on respect and mutual understanding, such as to allow an improvement of conditions. It is the redefinition of the relationship between conflict parties consenting to coexistence and perceiving the effective achievement of reconciliation as the best guarantee of future peace. Put simply, although too generally, he asserts that it consists of "a process through which a society moves from a divided past to a shared future" (Bloomfield 2003). Moreover, he considers the search for truth, justice and forgiveness a fundamental factor for the process. This poses the definition proposed closer to the view of many scholars that see reconciliation as involving the pursuit of justice, dialogue and rebuilding mutual trust (Ferati-Sachsenmaier 2019). These scholars define this process as a complex process taking place in contexts of divided societies that consist of the relation between trauma, truth, history and politics and justice. However, the OSCE identifies reconciliation as "a process that aims to overcome conflicts by breaking vicious cycles of mutual misperceptions and divisive memories that often result in violence, through the transformation of political and societal relationships." (OSCE 2018a). In addition, it understands reconciliation as an inclusive process that has an effect both at the political and at the civic level; for this reason, it recognises the importance of involving a variety of civil society organisations in the process (ibid.). This offers a more complete and clear understanding of the process as it also recognises the importance of building trust and confidence, of promoting dialogue and tolerance and of transitional justice in post-conflict societies. For this reason, the present paper takes into consideration this definition of reconciliation.

Among other things, transitional justice has a great role in the process of reconciliation because it allows the formation of a shared memory of the past in post-conflict societies such as that present in the Western Balkans; hence, it is a necessary tool for maintaining peace in the long term. Transitional justice involves widespread truth and justice mechanisms, including human rights trials, truth commissions, reparations, lustration, apologies, memorialisation practices, institutional reform as well as local, non-traditional forms of justice (Volčič and Simić 2013; Mihr 2013). Since the admission of guilt and the punishment of perpetrators are necessary for re-establishing trust and dialogue among communities, it has become a primary element in the democratisation process of the region encouraged by the international community (Ostojić 2013). International actors such as the United Nations have sought the institutionalisation of transitional justice in order to guarantee the reconciliation process. 
In the Western Balkans, the phenomenon saw the creation of international, national and local levels of war crime trials. In this context, the establishment of the International Criminal Tribunal for the former Yugoslavia (ICTY) initially stood out as an instrument that would bring justice and that could give a chance to start again the relations among the divided parties. However, it soon failed to produce the expected outcomes as the trials became politicised because collaboration with the ICTY was linked to the Euro-Atlantic integration of the countries in the region (Subotić 2009). Consequently, the ICTY was perceived as unfair in countries such as Serbia, mostly because of the media campaigns that aimed at depicting Serbian convicts as martyrs and the ICTY as privileging some parties and disfavouring others; thus, the court saw its truth-telling agenda undermined (Ostojić 2013). Against the loss of legitimacy to act of the ICTY, the OSCE serves as an actor that is fostering judicial truth; in fact, the organisation has established a war crimes trial monitoring programme in order to enhance transparency and reliability in the state and the judiciary. The programme, based on the principles of objectivity and non-intervention, observes and reports on all war crimes cases in Bosnia and Herzegovina (BiH), but it also goes further by undertaking capacity-building and technical-assistance initiatives in order to enhance the efficacy of war crimes processing (OSCE 2018a).

Apart from the lack of legitimacy of the ICTY in the context of the judiciary aspect of transitional justice, the poor political will among the divided parties has been another considerable constraint to reconciliation. In fact, official apologies from one side have come together over time with apologies from other sides through a series of declarations and official visits to former places of conflict, in a process that sees national political elites often waiting for the others' apologies before considering to do the same (Banjeglav 2013). This has led over time to political elites opening up about the question of truth seeking, although they have followed transitional justice measures mostly in the light of progressing with the process of Euro-Atlantic integration, as transitional justice has become increasingly a part of the regional integration process into the EU and NATO since it has become part of the conditionality to join the two institutions (Subotic 2009). Official acknowledgements of the harms done and apologies constitute a weak point for politicians, because they are aware that the recognition of war crimes might not be well received in their domestic setting, and thus could undermine their popularity; this leaves the burden of reconciliation to more reformist political forces (Petričušić and Blondel 2012). For this reason, truth seeking happens often in contexts in which the actors victimise their own group, resulting in mutually exclusive recognition of truth. Nevertheless, on other occasions, different groups have come to terms and together have accepted a common understanding of certain historical facts, however, at the expenses of a third group. This was the case of Croatia and Montenegro concerning the military campaign against Dubrovnik carried out by the Yugoslav National Army and by Montenegrin forces in 1991. In that occasion, Montenegro apologised to Croatia asserting that it was manipulated by directives coming from Belgrade, thus blaming the Yugoslav authorities in Serbia for the assault (Horelt 2015). This kind of behaviour allows the different conflicting parties to settle issues among them without taking any direct 
responsibility, thus without provoking domestic resentments. In other cases, politicians have agreed, despite domestic controversies, to acknowledge their country's involvement in certain controversial episodes of the war but have diminished the internal debate on the issue, thus constraining the possibility to develop domestic consciousness; this was the case of Serbia and the 2010 acknowledgement of the Srebrenica massacre in which the domestic political elite agreed to recognise the event but did not allow a domestic debate on the issue, thus limiting the ability of society to reckoning with the past (Ostojić 2013).

Thus, the political elites in the Western Balkans so far have demonstrated, with some exceptions, a certain indifference towards encouraging the reconciliation process in order to achieve other goals. Accordingly, the international community has tried to foster inter-ethnic rapprochement, although with a lack of legitimacy in the judicial framework as a consequence of the politicisation of the ICTY. Against this background, international organisations interested in the area and dealing with the process have sought to involve different actors in order to re-establish trust and dialogue among communities. Indeed, reconciliation is an inclusive process involving both the political and the civic spheres that need to address different actors (Perry 2009; Petričušić and Blondel 2012). In this sense, the international community has understood civil society actors as those that could encourage building mutual trust and tolerance to a broader degree. The involvement of civil society in the process is beneficial to the extent that it promotes direct participation of citizens, as well as being important sources of information providing first-hand knowledge of local circumstances. This has the potential to transform social relations in post-conflict societies (Volčič and Simić 2013). Consequently, international actors have started to emphasise the local dimension of stabilisation and conflict-prevention measures as necessary to sustain and build peace (Simangan 2019). Local stakeholders provide the means and the competences to efficiently pursue reconciliation strategies, and the aid of international agents can provide them with these tools. On the other hand, in order to engage in reconciliation practices efficiently, international stakeholders need to be acquainted with the cultural context of the area, a skill that is enabled through the involvement of local civil society (Lederach 1997).

\subsection{Civil Society in the Western Balkans}

Over the past decades, the term 'civil society' has generated a wide debate on its meaning. It has been described as spheres of social life that are situated between the domestic life and the state that allow the possibility of concerted action and social self-organisation (Bryant 1995), or as a set of different non-governmental institutions that is strong enough to balance the state so as to prevent the state from controlling the whole of society, while avoiding the constraint of the state's role as keeper of peace and authority (Gellner 1995). However, civil society and civil society organisations (CSOs) are generally understood in broader terms as "the arena, outside of the family, 
the state and the market, which is created by individual and collective actions, organisations and institutions to advance shared interests" (CIVICUS: World Alliance for Citizen Participation 2012). This definition allows the wider understanding of civil society as being composed of "a diverse body of civil actors, communities, and formal or informal associations with a wide range of roles, who engage in public life seeking to advance shared values and objectives" (OSCE 2018b). Thus, civil society comprises actors such as community and religious leaders, the media, international and local non-governmental organisations, charitable and philanthropic foundations, academic and research institutions and community groups and public associations. Civil society development is also widely accepted to be an indicator of the level of democratisation of a state as well as one of the main contributors to the democratisation process of former authoritarian states (Volčič and Simić 2013; Strazzari and Selenica 2013). In addition, civil society is recognised to be an agent with the capability to protect citizens from potentially aggressive states. Its existence in societies provides citizens with a framework in which they can develop trust and tolerance by interacting outside the private sphere and in the public one (Volčič and Simić 2013).

The local aspect in processes of peace-building and peace-keeping led by international stakeholders has been emphasised on different occasions by international organisations themselves, as it was the case with United Nations in 2015 when it reviewed its peace-building architecture as a task to be achieved by national stakeholders, while international actors, for their part, can help the process but not lead it (United Nations 2015; Simangan 2019). In a similar way, the OSCE strongly encouraged participating states to engage with civil society in the Western Balkans in order to tackle violence, acknowledging the potential of involving the public sphere in the process of reconciliation (OSCE 2018b). Indeed, the international community understands an engaged community as one that is able to create its own political reality and that has the potential to deal with its turbulent past (Volčič and Simić 2013), producing preconditions for long-lasting peace, thus making its development almost indispensable for the reconciliation process. In addition, civil society is able to raise awareness of discrimination and hate crimes and to break the cycle of violence in post-conflict contexts (OSCE 2018b). This capability comes from the very features of civil society because it is locally rooted, and thus, it has legitimacy in the community in which it operates as well as direct access to and influence on the group's needs and interests. In the context of the Western Balkans, international organisations have encouraged the spread of civil society actors, recognising their important role in the construction of and support to democratic institutions and political culture, which as a result has led the region to host a great number of civil society organisations (OSCE 2018b). For instance, in $\mathrm{BiH}$, the organisations registered by 2010 amounted to more than 12,000, while in Kosovo the number of registered NGOs in the same period was around 6000 (Belloni 2019; Strazzari and Selenica 2013). Consequently, due to its bottom-up characteristics, civil society stood out immediately in the aftermath of the Yugoslav wars as driver of change in the region (Simić 2013; McEvoy and McGregor 2008). The established civil society organisations work in different fields concerning democratisation, post-conflict stabilisation and rule of law (OSCE 2018b), following the neoliberal peace-building idea of the importance of security and human rights 
(Belloni 2019). However, the flourishing civil society did not manage to meet the expectations of its role as driver of change because of barriers imposed by different factors.

First of all, civil society in the Western Balkans is excessively financially dependent on international donors, the main ones being the European Union and the United States Agency for International Development (USAID) (Ostojić and Fagan 2014). The international financial support to civil society aimed to develop the latter as a means for policy development, pointing at the pressuring capabilities of local stakeholders (Fagan 2010). However, over time, civil actors did not manage to become independent from international funding because of the poor economic situation of the area; thus, they had to keep relying on foreign funds in order to continue their activities. However, this brought about severe consequences as civil society started to reflect the interests of its supporters and growingly lost legitimacy in the eyes of local communities (Kostovicova and Bojicic-Dzelilovic 2013; Ostojić and Fagan 2014). Hence, the population progressively developed feelings of distrust towards civil society actors, especially NGOs, as their influence was perceived as foreign interference into domestic issues, and as locals did not feel that their interests were being truly protected by them. This situation has been affecting the civil society sector in the Western Balkans for a long period, as confirmed by the USAID Civil Society Organisation Sustainability Index. The 2017 Index, which measures the level of development in civil society sectors, confirms that in the last decade no real improvement has been achieved regarding the financial independence of the civil sector in the region (USAID 2018).

Another issue for civil society in the Western Balkans is the ethnic division of its actors. In the region, as a result of the conflicts and the economic instability caused by them, affiliation to ethnic identities became stronger, as it provides a sense of security to the components of a given community (Branković et al. 2017). Therefore, the strengthened ethnic belonging inevitably reversed on local civil society actors. In fact, the local turn in reconciliation processes might bring about a resurgence of favourable conditions for conflicts as a result of the unsettled tensions (Simangan 2019). Throughout the years, civil society actors in the region have tended to emerge according to their ethnic affiliation, rather than expressing the interests of the mass (Mujkić 2007; Belloni 2019). This was particularly the case of Kosovo; Kosovar civil society emerged in the light of the regional turmoil in the 1990s and was strongly linked to the quest for national self-determination, providing alternative structures to the Serbian state. On the other hand, the Serbian minority in Kosovo kept following the directives coming from Belgrade, and this led to the creation of parallel societal and institutional structures in Kosovo that operate as an effective social welfare system (Strazzari and Selenica 2013; Ferati-Sachsenmaier 2019). Against this background, the reconciliation initiatives in Kosovo were endorsed and supported by the media and politicians only when they fit the political interests of political stakeholders, thus giving emphasis to the efforts of the Kosovar civil society only when they were portraying the Kosovar Albanians as victims of the hostilities; as a result, the domestic debate about the conflict became polarised (Ferati-Sachsenmaier 2019). At 
the same time, $\mathrm{BiH}$ has also experienced problems linked to ethnic identities constraining the potential of civil society in the process of reconciliation, although in the country, the limits came from the divided nature of the Bosnian state itself. In fact, an organisation is automatically linked to an ethnic group because of the place in which it was registered; thus, the chances of involving other ethnic groups are constrained as the ability of local civil society actors to prompt a wider debate at the national level (Žeravčić and Biščević 2009; Belloni 2019). Furthermore, as a consequence of the ethnicisation of advocacy groups in the region, the Western Balkans have seen over the years a rise in the amount of illiberal civil society organisations that are using conservative and ethno-nationalist arguments in order to resist the process of reconciliation to avoid recognising their share of the blame for the conflict (Kostovicova and Bojicic-Dzelilovic 2013; Džihić et al. 2018; Belloni 2019).

The third issue affecting civil society in the Western Balkans is that coordination among different civil society actors has not developed enough (OSCE 2018b). Cooperation at the regional level is difficult to achieve and almost non-existent. Consequently, common projects do not take place, or they do so only in exceptional cases. However, this does not apply to those NGOs that are focusing on human rights across the Western Balkans, as their aims cause them to be more open to regional cooperation with other civil society actors throughout the region, at least in most cases (Kostovicova and Bojicic-Dzelilovic 2013). Nevertheless, those NGOs engaged in programmes involving reconciliation and operating at the national level fall back into the domestic discourses of ethnic self-victimisation as a consequence of their politicisation. This was especially the case for Serbia's civil society organisations that had the aim of promoting domestic debate about the offences carried out by the Serbian side during the Yugoslav wars; in this circumstance, the local organisations reinforced the self-victimisation narratives typical of nationalistic parties instead of denouncing the wrongdoings done in the past because their legitimacy was put under pressure by allegations claiming that they were working against the integrity of the Serbian state (Ostojić 2013). In the Serbian case, as in that of other countries, NGOs adapted to the stances of their domestic political environment in order not to lose legitimacy in the eyes of authorities and to keep open dialogue with them. In any case, civil society organisations across the region commonly suffer from a lack of cooperation with national governments (OSCE 2018b). In order to tackle the lack of communication between civil society and authorities, international organisations can support NGOs and local stakeholders in order to allow them to carry out their functions as pressure groups. However, considering what is mentioned above, advocacy groups are unfavourably perceived as they are heavily financially supported by international actors and thus are understood as being the carriers of the interests of external forces rather than of their own society. Against this background, the OSCE stands out as one of those international agents that are succeeding in supporting civil society activities in the process of reconciliation in the Western Balkans without resorting to providing financial aid. 


\subsection{The Involvement of the OSCE in the Reconciliation Process}

The OSCE has been present in the region since its first mission started in North Macedonia in 1992. The OSCE Spillover Mission to Skopje was launched in the light of the tensions in the area that were threatening the stability of Macedonia. Since then, the OSCE has been credited as one of the most reliable international institutions involved in the Western Balkans for the process of stabilisation, peacebuilding and peace-keeping of the region (Galbreath 2007). The peculiarity of the OSCE when contrasted to other international institutions is that the organisation is based on a common and more comprehensive idea of security and that it is the only pan-European security institution that has linked the human dimension of security to the political-military concept of security (Galbreath and Seidyusif 2014). Indeed, the third dimension of security encompassing the OSCE points explicitly at the human dimension as necessary in order to guarantee security in the OSCE area. In this sense, the organisation aims to develop security in all its dimensions, being it economic, political, military, environmental or human, by involving in the process all the necessary agents that could contribute to it. However, talking about the efforts of the OSCE regarding the reconciliation process in the Western Balkans does not come so easily as the missions of the organisation in the different countries in the region are not directly aimed at the process, thus not all of them fall under the scope of third security dimension. For instance, while the OSCE Mission in Kosovo focuses on human and community rights, democratisation and public safety (OSCE 2017a), the OSCE Mission in Serbia focuses on the development of the democratic system and rule of law in Belgrade (OSCE 2018c). Despite not pointing directly to reconciliation in some cases, the missions and field operations of the OSCE contribute to the process actively. Indeed, the OSCE recognises reconciliation as a necessary instrument to achieve peace-building and in order to assure long-term stability and peace in the OSCE area; thus, all the actions that the organisation pursues towards the achievement of its goals also tackle the issue of reconciliation. As former Secretary General of the OSCE Lamberto Zannier pointed out in the opening speech of the workshop Towards a Strategy for Reconciliation in the OSCE Area held in Vienna in 2012, the OSCE facilitates reconciliation across all three dimensions of security by building confidence between police and ethnic communities, by bringing civil society groups in ethnically divided contexts together with local government institutions, encouraging regional cooperation regarding trade, energy and the environment and by promoting contacts between diverse ethnic groups (OSCE 2013).

To date, the OSCE has worked to allow judicial and legal reforms in the Western Balkans as part of its efforts to develop democratic institutions in post-conflict societies. The efforts of the organisation in fostering reforms came after it had identified a serious lack of political support for war crimes processing as well as interferences in proceedings (Jones et al. 2013). In order to tackle these issues, the OSCE has developed a programme aimed at monitoring war crimes trials (OSCE 2018a). In addition to this, the OSCE has provided capacity building and technical support 
to the six countries' judicial systems, helping them to follow their constitutions and criminal procedure codes. Moreover, the organisation has improved the transparency of procedures, while avoiding interference in the judicial processes and allowing the public and NGOs to become the report recipients, thus encouraging trust-building towards institutions while increasing involvement of the public sphere in the process of transitional justice. Furthermore, in order to sustain transitional justice, the OSCE has promoted dialogue regarding the past in $\mathrm{BiH}$ by depoliticising the issue of establishing platforms in which the government, institutions and civil society could further the process of reconciliation (ibid.). As already mentioned, the OSCE puts a strong emphasis on carrying out its tasks in an inclusive way involving different key agents. Indeed, the efforts in pursuing transitional justice show exactly this feature. Against this background, the OSCE stands out among the different international organisations because of its ability to involve and support civil society actors in the process of reconciliation. Indeed, the OSCE missions in the different countries have supported local NGOs working to trigger judicial reforms. Among these civil society organisations, the Association of Public Prosecutors and Deputy Public Prosecutors of Serbia has carried out important actions in this sense. In 2013 and 2014, this NGO, supported by the OSCE Mission to Serbia and by the Embassy of Netherlands in Belgrade, has implemented the project 'Strengthening Independence and Integrity of Prosecutors' with the main goal of supporting the role and perception of the State Prosecutorial Council. Despite not being directly linked to reconciliation, reforms of the judiciary and the strengthening of transparency of court trials are essential in order to ensure the truth-telling potential of the judicial system (Association of Public Prosecutors and Deputy Public Prosecutors of Serbia 2015).

The relationship of the OSCE with civil society has a long history, drawing back to the mid-1970s when the organisation was founded as Conference on Security and Co-operation in Europe (CSCE); the CSCE gave much support to rising civil society actors in Central and Eastern Europe before the end of the Cold War and kept up this productive relationship in the aftermath of the fall of the Berlin Wall, when the Conference was institutionalised in 1994 and became an organisation. Today, the OSCE recognises the primary role of civil society actors, focusing especially on NGOs, in the field of democratisation and conflict prevention (Mayer 2008). In their efforts to tackle hate crime, they are perceived as agents providing supervision and reports on hate crime incidents, supporting victims and raising awareness on the issue (OSCE/ODIHR 2018). Thus, the organisation undertakes initiatives together with these actors, providing them with technical-assistance and capacity-building initiatives (Mayer 2008). In particular, the OSCE offers occasions for creating networks among NGOs in the region, thus tackling the lack of regional coordination and cooperation among civil society agents. In particular, OSCE supported projects such as 'Fostering NGO Human Rights Network in the Western Balkans Region', which then transformed in a well-established network of civil society organisations. The network comprises NGOs such as the Humanitarian Center for Integration and Tolerance and the Group 484 in Serbia, the Center for Peace, Non-Violence and Human rights in Croatia and the Serbian Democratic Forum and Vaša Prava in BiH. The network was born by the recognition of the OSCE of the divisions between civil 
society actors in the region. The goal of its creation was the strengthening of civil society organisations links with each other in order to improve their pressuring and advocacy potentials (Group484 2014). The network of these NGOs deals mostly with supporting and protecting the rights of forced migrants in the region, thus also helping the process of regional reconciliation as the Yugoslav wars caused several displacements of people, and as their return has been demonstrated to be difficult in some cases.

Nevertheless, the OSCE is not able to provide a high level of funding to civil society actors because of its lack of financial capabilities (Ostojić 2013); on the other hand, the OSCE's Office for Democratic Institutions and Human Rights (ODIHR) uses a limited budget to support small grass-root projects that are articulated by OSCE's Missions in each country that are carried out together with local civil society actors (Mayer 2008). The lack of financial support provided by the OSCE might bring local civil society actors to turn to other international organisations in order to obtain more secure funds. This might prompt local NGOs to start doing international agents' interests instead of those of their societies in order to gain funding. Nevertheless, the OSCE results freed from the danger of inhibiting the real needs of local advocacy groups exactly because of its scarce sources of funding, thus meaning that those NGOs that engage with the organisation are doing so not for the sake of money. In addition, the organisation stands out in the region because of its attention towards civil society in contraposition to other international institutions. Indeed, while advocacy groups in Kosovo have lamented a superficial involvement of the UN Interim Administration Mission in Kosovo (UNMIK) because of the consultations it carried out with the local elites, thus leaving behind local civil society actors, prompting in them feelings of mistrust (Simangan 2019), the OSCE has always pursued a different approach to these actors. For instance, the Democratisation Department of the OSCE established an Interim NGO Council inviting NGOs registered with UNMIK to attend in order to allow the rising civil society groups in 1999 to take part in the process of institution building of the country (Strazzari and Selenica 2013). The OSCE has a in-depth mechanism for civil society groups and, despite NGOs not taking part in its political decision-making process, they meet regularly with the Secretary General of the institution and have a strong relation with permanent OSCE delegations; thus, they are able to raise their concerns and interests in order to advise the organisation of the necessity to deal with certain issues (Mayer 2008).

\subsection{Empowering Women}

In order to facilitate dialogue and reconciliation among conflicting parties in the Western Balkans, the OSCE engages and supports different civil society groups, with a major focus on women, youth groups and community and religious leaders. In relation to women, the OSCE focusses a particular attention on them because of their acknowledged role as agents of social change (OSCE 2018a, b). One of the most successful efforts of the organisation in pursuing dialogue among different 
societies resides in the initiative that was launched by the OSCE Mission to Serbia together with the OSCE Mission in Kosovo that is known under the name 'Follow Us'. This initiative was started in 2012 and brought together renowned women from Serbia and Kosovo who are members of parliament, journalists, academics and civil society activists; the meetings focus on gender issues, a common point between the parties, and progressed to include social and economic topics. The initiative, met initially with scepticism from both sides, was successful in building reciprocal trust and dialogue and managed to overcome political turmoil between the two countries over the years, always allowing for an open channel of communication. The main goal of 'Follow Us' is to promote women's active lives in public and political spheres as role models and promoters of peace, reconciliation and tolerance. This succeeded to the extent that the initiative may expand to other OSCE areas where societies are experiencing strong divisions and conflicts (OSCE 2016, 2018a). As part of the 'Follow Us' initiative, both the OSCE Mission in Serbia and the OSCE Mission in Kosovo have established the Dialogue Academy for Young Women. The Academy, which at the moment of writing is in its fifth edition, consists of bringing together young women for 10 days from Pristina and Belgrade with the aim of encouraging collective initiatives of young women's activists from both societies to advocate for women's rights and trust-building in the region (OSCE 2018d).

\subsection{Involving Youth and Education}

Another crucial component of civil society with which the OSCE engages actively in promoting reconciliation is the youth. Indeed, the organisation has already proved its dedication to youth with the establishment of the Youth Advisory Group in BiH in 2014 with the goal of giving more importance to the opinions of younger generations in the projects pursued by the OSCE. In its activities, the organisations try to bolster youth engagement by supporting youth-focused initiatives. Among these initiatives stands out, the organisation of summer and winter schools for young people coming from areas of conflict is aimed at enhancing the intercultural dialogue and trust-building (OSCE 2018a). In addition, the OSCE Presence in Albania has organised in 2017 together with the Municipality of Tirana, the Austrian Development Agency (ADA) and the Regional Youth Cooperation Office (RYCO) a youth trail in order to raise awareness of OSCE values and to promote tolerance as means to achieve regional security (OSCE 2017b). Moreover, as emphasised during a workshop in 2012, the OSCE puts emphasis on projects revolving around building tolerance and inter-ethnic trust among younger generations, such as those comprising artistic initiatives (OSCE 2013). Indeed, the organisation has pursued such initiatives successfully, for example one organised by the OSCE Mission to $\mathrm{BiH}$ that sought to sensitise young people, through creative means involving dramatic arts, towards issues regarding radicalisation and violent extremism, which is a topic that can be tackled by reconciliation. Overall, the initiative involved university students from 
Sarajevo and Banja Luka (OSCE 2018b). Furthermore, in order to help younger generations to overcome ethnic prejudices and rebuild inter-ethnic trust, but also because of its importance for achieving sustainable peace in post-conflict societies, the OSCE is highly concerned with the educational systems in the region, which especially in cases such as Macedonia and $\mathrm{BiH}$ comprise segregated schools. Against this background, the organisation supports the desegregation of school systems while seeking the involvement of civil society organisations in the process. These organisations have tried to promote integration by implementing activities and acting where the national institutions were unable or lacking political will to do so. Nowadays, the OSCE intervention, as well as the efforts of civil society, in Macedonia has been shown to have successful results in reducing school violence but also in involving the state in the process, thus prompting reforms in the educational system. On the other hand, the positive outcomes accomplished in Macedonia did not take place in $\mathrm{BiH}$, where the efforts of civil society organisations and the guidance of the local OSCE Mission were reduced by the lack of support from the national institutions (Galbreath 2007; Barbieri et al. 2013; Kavaja 2017). Against this background, the NGO Vaša Prava has strongly engaged in efforts aimed at changing the 'Two School Under One Roof' policy in BiH. In 2012, the NGO filed suit in the HerzegovinaNeretva Canton, in Mostar, arguing that the education policy of the country was against the anti-discrimination law. The lawsuit ended up eventually in the hands of the Federation of $\mathrm{BiH}$ Supreme Court, which held that the policy was violating the law on discrimination. Nevertheless, the decision applied to the schools in Mostar but did not spread throughout the country because it would need the initiative of the government. Hence, Vaša Prava needs to put pressure on other cantons in order to achieve its goal. The NGO tried to do so also in Travnik, in the Central Bosnia Canton, but the court dismissed the claim citing language barriers and the parents' lack of concern for the issue.

\subsection{Engaging with Religious Leaders}

In the process of reconciliation in the Western Balkans, a tremendous role is played by leaders of religious communities because of their abilities in acting as mediators between conflicting groups, as they normally enjoy popular and political influence (OSCE 2018b). For this reason, the OSCE started to collaborate with religious leaders in an attempt to foster tolerance and re-open dialogue among divided societies. The organisation established an inter-faith dialogue framework in order to allow different religious communities to come in contact with the support of their religious leaders. In addition, the OSCE, apart from providing several occasions for inter-religious dialogue such as exhibitions, meetings of religious guides and sports events, has worked hard to allow for the first inter-faith meeting for paying respects together for the victims of war crimes from other ethnic groups (OSCE 2018a). Interesting and positive outcomes have come from the initiative led by the OSCE Mission in Kosovo that involved high school students from the municipality of Kaçanik/Kačanik 
in a tour of sites belonging to different religious communities in the city of Prizren. The initiative also comprised discussions with different religious representatives and saw the participation of the Minister of Culture, Youth and Sport (OSCE 2018b). Eventually, the efforts of the organisation have resulted in successful outcomes as the different local religious communities are now working jointly against hate crimes and in order to re-establish inter-ethnic confidence and tolerance, while also publicly condemning incidents.

In many ways, the OSCE has been able to overcome many of the issues affecting the reconciliation process in the Western Balkans and the civil society of the region. Despite the scarce funding opportunities that the organisation can provide, civil society has enjoyed the support by the OSCE and consequently it managed to broaden its capacities. In addition, the organisation is providing civil society with important networking opportunities by bolstering regional cooperation between different NGOs and between civil society actors, and with support to engage with local authorities, allowing it to play its role as pressure group.

\subsection{Conclusion}

The argument advanced in this chapter is that civil society is benefitting from the support of the OSCE in pursuing reconciliation in the Western Balkans. The aid coming from the organisation is to support civil society groups in order to overcome the barriers they face in a context such as the one in the region. The obstacles faced by advocacy groups are mainly the lack of strong networks among themselves and with local authorities; their insufficient legitimacy as a consequence of their financial dependency on international donors; and in some cases, their politicisation as a result of their ethnic affiliation. Against this background, the OSCE has provided the necessary tools in order to foster regional security and engage different civil society groups in different ethnic communities. Indeed, the inclusive approach towards security of the organisation has favoured its activities, and consequently, it has experienced a positive response from advocacy groups who engage with it energetically. Indeed, as the reconciliation process needs to tackle both the civic and the political spheres of post-conflict societies, the organisation's approach appears the most effective one as it deals with both of these spheres, engaging simultaneously with governments and with civil society. Regarding the latter, the OSCE allows inter-ethnic engagement via groups of women, youth and leaders of different religious communities, all of whom are agents with an enormous potential for the development of reconciliation, and encourages interactions through initiatives both at the local and at the regional level. Furthermore, more locally oriented, it also supports capacity-building activities by providing training sessions, recommendations and guidance aimed at improving civil society's capabilities. Even more fundamentally, the OSCE has managed to support civil society organisations in engaging with governmental institutions and actors, which are often reluctant to engage in initiatives entailing reconciliation, thus allowing them to play their role as pressure groups. This has brought positive outcomes in 
certain occasions, as shown by the cases of 'Follow Us' and of the efforts in desegregating schools in North Macedonia. Furthermore, the organisation has bolstered transparency in reconciliation procedures aimed at achieving transitional justice by establishing war crimes trial monitoring programmes. On the other hand, advocacy groups that engage with the organisation have offered their contribution to the activities of the OSCE in reporting and monitoring their local environments, especially regarding hate crimes and security threats.

Despite the efforts of the OSCE having been overshadowed by those of other international institutions such as the EU because of the huge disparity of budgetary possibilities, the organisation has established itself as an indispensable actor in the Western Balkans for the process of reconciliation. Building inter-ethnic confidence and tolerance is allowing the region to move forward and to transform itself into a more secure environment. Nonetheless, the six countries still have a long way to go before achieving reconciliation, taking into consideration that the process itself requires long-term efforts but also that the current regional cooperation level among them is still quite low. Against this background, the OSCE has the necessary potential to keep going with the positive developments and to enhance the abilities of civil society agents the way it has been doing this far. Indeed, the organisation has provided until now the necessary transformative impulse in certain contexts, strengthened by the mutual aid of the local civil society. The stabilisation of the Western Balkans requires further civil society involvement in order to allow the involved divided societies to both deal with the past and look at the future, and the OSCE has all the right means to assure it. To conclude, the reconciliation process is important for assuring stability, peace and security as its achievement would mean that the cycle of violence has been broken and that mutual trust and tolerance in post-conflict societies has been guaranteed. The OSCE work, together with the civil society of the Western Balkans, is progressing in implementing the process and, despite the final goal still being far from reach, their joint efforts are allowing the development of inter-ethnic rapprochement. Thus, by promoting and supporting civil society progression and regional networks, and by providing them with the necessary expertise assistance, the OSCE is actively engaged in transforming the social and political context of the Western Balkans.

\section{References}

Association of Public Prosecutors and Deputy Public Prosecutors of Serbia. (2015). Strengthening independence and integrity of prosecutors. Retrieved from https://en.uts.org.rs/projects/1011strengthening-independence-and-integrity-of-prosecutors. Accessed on 12/10/2019.

Banjeglav, T. (2013). Dealing with the past in post-war Croatia: Perceptions, problems, and perspectives. In Z. Volčič \& O. Simić (Eds.), Transitional justice and civil society in the Balkans (pp. 33-50). New York, NY: Springer.

Barbieri, S., Vrgova, R., \& Bliznakovski, J. (2013). Overcoming ethnic-based segregation: How to integrate public schools in Macedonia and Bosnia and Herzegovina. Skopje and Sarajevo.

Belloni, R. (2019). The rise and fall of peacebuilding in the Balkans. London: Palgrave Macmillan. 
Bloomfield, D. (2003). Reconciliation: An introduction. In D. Bloomfield, T. Barnes, \& L. Huyse (Eds.), Reconciliation after violent conflict: A handbook (pp. 10-18). Stockholm: International IDEA.

Branković, M., Turjačanin, V., \& Maloku, E. (2017). Setting the stage: Research on national, ethnic, and religious identities after the recent violent conflicts in the Western Balkans. In F. Pratto, I. Žeželj, E. Maloku, V. Turjačanin, \& M. Branković (Eds.), Shaping social identities after violent conflict (pp. 13-51). London: Palgrave Macmillan.

Bryant, C. G. (1995). Civic nation, civil society, civil religion. In A. J. Hall (Ed.), Civil society. Theory, history, comparison. Cambridge.

CIVICUS: World Alliance for Citizen Participation. (2012). State of Civil Society 2011, Johannesburg, South Africa.

Džihić, V., Draško, G. P., Turčalo, S., Beshku, K., \& Cerovac, I. (2018). Overcoming the democratisation deficit in the Western Balkans: A road to (no)where?. Belgrade: Friedrich-Ebert-Stiftung.

Emini, D., \& Marku, D, (2019). Regional Security Cooperation in the Western Balkans. Institute for Democracy "Societas Civilis". Skopje, North Macedonia.

Fagan, A. (2010). Europe's Balkan dilemma: Paths to civil society or state-building? London: I.B Tauris.

Ferati-Sachsenmaier, F. (2019). Postwar Kosovo: Global and local dimensions of interethnic reconciliation processes. International Journal of Transitional Justice, 1-18.

Galbreath, D. J. (2007). The organization for security and co-operation in Europe (OSCE). New York, NY: Routledge.

Galbreath, D. J., \& Seidyusif, A. (2014). Organization for security and cooperation in Europe. In J. Sperling (Ed.), Handbook of governance and security. Northampton, MA: Edward Elgar.

Gellner, E. (1995). In J. Hall (Ed.), The importance of being modular (pp. 32-56). Cambridge: Civil Society.

Group484. (2014). Determination of residence status of displaced persons in Western Balkans Countries. Retrieved from https://www.osce.org/odihr/124949. Accessed on 21/10/2019.

Horelt, M. A. (2015). Serbia-Croatia, Bosnia and Herzegovina: Different apology packages, different successes. In C. Daase, et al. (Eds.), Apology and reconciliation in international relations (pp. 164-194). New York, NY: Routledge.

Jones, B., Jeffrey, A., \& Jakala, M. (2013). The 'transitional citizen': Civil society, political agency and hopes for transitional justice in Bosnia-Herzegovina. In Z. Volčič \& O. Simić (Eds.), Transitional justice and civil society in the Balkans (pp. 87-103). New York, NY: Springer.

Kavaja, K. (2017). Ethnicity, politics, and education in Macedonia. European Journal of Education Studies, 480-494.

Kostovicova, D., \& Bojicic-Dzelilovic, V. (2013). Introduction: Civil Society and Multiple Transitions-Meanings, Actors and Effects. In V. Bojicic-Dzelilovic, J. Ker-Lindsay, \& D. Kostovicova (Eds.), Civil society and transitions in the Western Balkans (pp. 1-25). London: Palgrave Macmillan.

Lederach, J. P. (1997). Building peace: Sustainable reconciliation in divided societies. Washington, DC: United States Institute of Peace Press.

Mayer, P. (2008). Civil society participation in international security organizations: The cases of NATO and the OSCE. In J. Steffek, C. Kissling, \& P. Nanz (Eds.), Civil society participation in European and Global Governance (pp. 116-139). London: Palgrave Macmillan.

McEvoy, K., \& McGregor, L. (Eds.). (2008). Transitional justice from below: Grassroots activism and the struggle for change. London: Bloomsbury Publishing.

Mihr, A. (2013). Transitional justice and the quality of democracy. International Journal of Conflict and Violence (IJCV), 7(2), 298-313.

Mujkić, A. (2007). We, the citizens of ethnopolitics. Constellations, 14(1), 112-128.

OSCE. (2013). Workshop on 'Towards a strategy for reconciliation in the OSCE Area': Key issues and recommendations. Retrieved from https://www.osce.org/sg/98698?download=true. Accessed on $06 / 10 / 2019$. 
OSCE. (2016). Women at the forefront of reconciliation, December 21, 2016. Retrieved from https:// www.osce.org/serbia/290301. Accessed on 04/10/2019.

OSCE. (2017a). OSCE launches regional youth trail initiative with Tirana Municipality to promote democratic values among young people, August 3, 2017. Retrieved from https://www.osce.org/ presence-in-albania/333906. Accessed on 06/10/2019.

OSCE. (2017b). Organization for security and co-operation in Europe: Mission in Kosovo. Priština. Retrieved from https://www.osce.org/mission-in-kosovo/143996. Accessed on 02/10/2019.

OSCE. (2018a). Building sustainable peace and democracy: OSCE experiences in South-Eastern Europe. Retrieved from https://www.osce.org/secretariat/383751. Accessed on 21/09/2019.

OSCE. (2018b). The role of civil society in preventing and countering violent extremism and radicalization that lead to terrorism: A guide for South-Eastern Europe. Retrieved from https://www. osce.org/secretariat/400241. Accessed on 22/09/2019.

OSCE. (2018c). Organization for security and co-operation in Europe: Mission to Serbia, Belgrade. Retrieved from https://www.osce.org/mission-to-serbia/285186. Accessed on 28/09/2019.

OSCE. (2018d). Fourth OSCE Dialogue Academy for Young Women concludes in Austria. Retrieved from https://www.osce.org/mission-in-kosovo/400577. Accessed on 25/10/2019.

OSCE/ODIHR. (2018). Guide to addressing hate crime at the regional level. Retrieved from https:// www.osce.org/odihr/402536. Accessed on 02/10/2019.

OSCE. (2019). Survey of OSCE field operations. Retrieved from https://www.osce.org/secretariat/ 74783. Accessed on 05/10/2019.

Ostojić, M. (2013). Facing the past while disregarding the present? Human rights NGOs and truthtelling in Post-Milošević Serbia. In: V. Bojicic-Dzelilovic, J. Ker-Lindsay, \& D. Kostovicova (Eds.), Civil society and transitions in the Western Balkans (pp. 230-247). London: Palgrave Macmillan.

Ostojić, M., \& Fagan, A. (2014). Donor strategies and practices for supporting civil society in the Western Balkans. Balkan Civic Pracfices No, 11.

Perry, V. (2009). A survey of reconciliation processes in Bosnia and Herzegovina: The gap between people and politics. In J. R. Quinn, (Ed.), Reconciliation(s): Transitional justice in postconflict societies. Montreal: McGill University Press (pp. 207-231).

Petričušić, A., \& Blondel, C. (2012). Reconciliation in the Western Balkans: New perspectives and proposals. Journal on Ethnopolitics and Minority Issues in Europe (JEMIE), 11(4), 1-6.

Simangan, D. (2019). A case for a normative local involvement in post-conflict peacebuilding. International Peacekeeping, 1-25.

Simić, O. (2013). 'Pillar of shame': Civil society, UN accountability and genocide in Srebrenica. In Z. Volčič \& O. Simić (Eds.), Transitional justice and civil society in the Balkans (pp. 181-199). New York, NY: Springer.

Strazzari, F., \& Selenica, E. (2013). Nationalism and civil society organisations in post-independence Kosovo. In V. Bojicic-Dzelilovic, J. Ker-Lindsay, \& D. Kostovicova, (Eds.), Civil society and transitions in the Western Balkans (pp. 117-134). London: Palgrave Macmillan.

Subotić, J. (2009). The paradox of international justice compliance. International Journal of Transitional Justice, 3(3), 362-383.

United Nations. (2015). Challenge of sustaining peace: Report of the advisory group of experts on the review of the peacebuilding architecture, A/69/968-S/2015/490.

USAID. (2018). 2017 Civil society organization sustainability index for central and eastern Europe and Eurasia. Retrieved from https://www.fhi360.org/sites/default/files/media/documents/ resource-civil-society-organization-2017-regional-report.PDF. Accessed on 25/09/2019.

Volčič, Z., \& Simić, O. (2013). Localizing transitional justice: Civil society practices and initiatives in the Balkans. In Z. Volčič \& O. Simić (Eds.), Transitional justice and civil society in the Balkans (pp. 1, 14). New York, NY: Springer.

Žeravčić, G., \& Biščević, E. (2009). Analysis of the civil society situation in Bosnia and Herzegovina. Sarajevo: HTSPE Ltd. UK and Kronauer Consulting. 
Open Access This chapter is licensed under the terms of the Creative Commons Attribution 4.0 International License (http://creativecommons.org/licenses/by/4.0/), which permits use, sharing, adaptation, distribution and reproduction in any medium or format, as long as you give appropriate credit to the original author(s) and the source, provide a link to the Creative Commons license and indicate if changes were made.

The images or other third party material in this chapter are included in the chapter's Creative Commons license, unless indicated otherwise in a credit line to the material. If material is not included in the chapter's Creative Commons license and your intended use is not permitted by statutory regulation or exceeds the permitted use, you will need to obtain permission directly from the copyright holder.

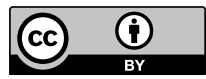

